\title{
CRYPTOSPORIDIOSIS IN INDONESIA: A HOSPITAL-BASED STUDY AND A COMMUNITY-BASED SURVEY
}

\author{
TATSUYA KATSUMATA, DANIEL HOSEA, EDDY BAGUS WASITO, SHIGERU KOHNO, KOHEI HARA, \\ PITONO SOEPARTO, AND IGN GDE RANUH \\ Department of Parasitology, Institute of Tropical Medicine, Nagasaki University, Nagasaki, Japan; Tropical Disease Research \\ Center, Airlangga University, Surabaya, Indonesia; Second Department of Internal Medicine, Nagasaki University School of \\ Medicine, Nagasaki, Japan
}

\begin{abstract}
Hospital-based and community-based studies were conducted to understand the prevalence and mode of transmission of Cryptosporidium parvum infection in Surabaya, Indonesia. In both studies people with and without diarrhea were examined for oocysts. A community-based survey included questionnaires to a community and stool examination of cats. Questionnaires covered demographic information, health status, and hygienic indicators. In the hospital, $C$. parvum oocysts were found in $26(2.8 \%)$ of 917 patients with diarrhea and $15(1.4 \%)$ of 1,043 control patients. The most susceptible age was less than two years old. The prevalence was higher during the rainy season. A community-based study again showed that $C$. parvum oocysts were frequently detected in diarrhea samples (8.2\%), exclusively during rainy season. Thirteen $(2.4 \%)$ of 532 cats passed $C$. parvum oocysts. A multiple logistic regression model indicated that contact with cats, rain, flood, and crowded living conditions are significant risk factors for Cryptosporidium infection.
\end{abstract}

The protozoan Cryptosporidium parvum is now recognized as an important cause of diarrhea in both immunocompetent and immunosuppressed patients. A number of surveys carried out in recent years have described the worldwide distribution of Cryptosporidium. ${ }^{1-10}$ The prevalence of Cryptosporidium infection is higher among children than among adults and is more common in developing countries than in developed countries. ${ }^{1-10}$ Infection occurs by ingestion of oocysts either through human-to-human or animal-to-human contact, or via contaminated water. ${ }^{5,6,11-16}$

Despite its wide distribution and obvious relevance to public health, Cryptosporidium remains a little-studied protozoan in Indonesia. The present studies were undertaken to 1) assess the importance of Cryptosporidium in the causation of acute diarrhea among patients of all age groups who visited a hospital, and 2) understand the community prevalence and the mode of transmission of Cryptosporidium infection in Surabaya, Indonesia.

\section{MATERIALS AND METHODS}

Study population and sample collection. Hospital-based study. Observations were made over a period of one year from August 1992 to July 1993 at the Dr. Soetomo Hospital, which is part of the University of Airlanaga in Surabaya. The hospital has 1,466 beds. During the study period, 92,061 patients visited the hospital and 41,622 patients were admitted. At total of 3,892 of 41,622 in-patients and 1,982 of 50,439 out-patients had diarrhea. The study population consisted of 917 patients with acute diarrhea: 715 in-patients and 202 out-patients. A group of 1,043 in-patients selected during the study period served as controls; none of these patients had any gastrointestinal problems. A stool specimen was collected from each patient within $24 \mathrm{hr}$ of visiting the hospital.

Community-based study. The studies were conducted in eight communities in Surabaya during the rainy season (December 1992 to March 1993) and dry season (June to July 1993). The total population of eight communities was approximately 10,000 . The study communities were composed of one or two communities that were randomly selected from five administrative districts of Surabaya. The study participants gave verbal informed consent allowing them to be eligible for the present cross-sectional study. For children, informed consent was obtained from parents or guardian. The study was approved by the Ethical Committee of the Tropical Disease Research Center of Airlangga University.

Surabaya is the second largest city in Indonesia, with a population of more than three million. People live in crowded conditions and floods are common during the rainy season. Inhabitants work mostly in commerce and industry. The public water supply is incomplete in the study area. Therefore, in some study areas, people use artesian well water. Since both piped water and well water are not fit to drink, people boil the water before using it. There are few dogs in this region and the cat is a common domestic animal.

Each study participant was given a plastic container for collection of stool samples and a questionnaire to be completed. The questionnaire covered the participant's age, sex, health status such as history of diarrhea and other symptoms, contact with domestic animals, personal hygiene facilities, source and treatment of drinking water, the presence of flooding during the rainy season, and living conditions such as the number of persons and rooms in the household.

Air temperature and rainfall data for the area during the period August 1992 to July 1993 were obtained from the Head Office of Meteorology in Surabaya.

To assess the prevalence of Cryptosporidium among domestic animals, the stool specimens of 532 cats and 4 dogs were collected by rectal swabs and examined for oocysts.

Laboratory procedures. Stool specimens were processed for detection of Cryptosporidium oocysts within $6 \mathrm{hr}$ after collection. Cryptosporidium oocysts were detected by microscopic examination of samples. Each stool sample was first subjected to Sheather's sugar flotation and smeared on a slide. The slides were first examined by phase-contrast microscopy at $600 \times$ magnification. Once oocysts appearing at phase-bright, birefringent bodies against a dark background were identified, the remaining concentrated sample was overlaid with saline and stained using the Kinyou-mod- 
TABLE 1

Age-specific distribution of Cryptosporidium parvum infection in a hospital-based study

\begin{tabular}{|c|c|c|c|c|}
\hline \multirow{2}{*}{$\begin{array}{c}\text { Age } \\
\text { group } \\
\text { (months) }\end{array}$} & \multicolumn{2}{|c|}{ Patients with diarrhea } & \multicolumn{2}{|c|}{ Patients without diarrhea } \\
\hline & $\begin{array}{c}\text { No. } \\
\text { examined }\end{array}$ & $\begin{array}{l}\text { No. }(\%) \text { with } \\
\text { C. parvum }\end{array}$ & $\begin{array}{c}\text { No. } \\
\text { examined }\end{array}$ & $\begin{array}{l}\text { No. (\%) with } \\
\text { C. parvum }\end{array}$ \\
\hline $0-11$ & 448 & $13(2.9)$ & 370 & $11(3.0)$ \\
\hline $12-23$ & 142 & $9(6.3)$ & 186 & $2(1.1)$ \\
\hline $24-59$ & 116 & $2(1.7)$ & 230 & $2(0.9)$ \\
\hline$>60$ & 211 & $2(1.0)$ & 257 & $0(0)$ \\
\hline Total & 917 & $26(2.8)$ & 1,043 & $15(1.4)$ \\
\hline
\end{tabular}

ified acid-fast technique. The slides were then examined to identify Cryptosporidium.

Stool specimens positive for Cryptosporidium were screened for other enteric bacteria by standard bacteriologic methods, for Rota virus by a latex agglutination kit (Rota screen 421-701; Denka Seiken, Tokyo, Japan), and for other intestinal helminth and protozoa by a formalin-ether concentration technique with iodine stain.

Statistical analysis. Data were analyzed using HALBAU (Institute of Statistical Mathematics, Tokyo, Japan) software. The statistical significance of the differences in proportions was tested by the chi-square test. Results were considered significant if the $P$ value was less than 0.05 . Logistic regression models were used to examine variables associated with cryptosporidiosis and were summarized by odds ratios and $95 \%$ confidence intervals. The following variables were incorporated into logistic regression models: age (as a continuous variable), sex, season (dichotomized as rainy season and dry season), diarrhea, contact with cats, water treatment for drinking, public bath bathing, flood in the rainy season, number of persons in household (as a continuous variable), number of rooms in household (as a continuous variable), living area (area $\mathrm{W}$ was used as a reference).
RESULTS

Hospital-based study. Cryptosporidium parvum oocysts were found in $26(2.8 \%)$ of 917 patients with acute diarrhea and $15(1.4 \%)$ of 1,043 control patients. Patients with diarrhea were more likely to have Cryptosporidium oocysts in their stool $(P<0.05)$. Cryptosporidium parvum was detected as sole pathogen in $23(2.5 \%)$ of 26 positive cases, and in combination with one or more other enteropathogens in the remainder. Two of the three cases of mixed infection were associated with enteropathogenic Escherichia coli and one with enteropathogenic E. coli and Ascaris lumbricoides.

The age distribution of patients with Cryptosporidium infection found is shown in Table 1 . There was a significant difference in the rate of infection among the different age groups $(P<0.05$ for diarrheic patients and $P<0.01$ for non-diarrheic patients). The highest rate was in those 0-23 months of age. No sex-specific difference was found for both diarrheic and non-diarrheic patients.

The prevalence of infection varied with month. The peak prevalence was recorded in March, the rainy season $(9.7 \%$ for diarrheic patients and $4.9 \%$ for non-diarrheic patients). Although no patients with Cryptosporidium infection were detected in December, the tendency was that the prevalence of infection was higher during the rainy season than the dry season $(P<0.01)$ (Figure 1$)$.

Community-based study. The results are shown in Table 2. The overall prevalence of C. parvum in the collected stool specimens was $1.1 \%$ (49 of 4,368): $8.2 \%$ (21 of 257) in diarrheic stool and $0.7 \%$ (28 of 4,111) in non-diarrheic stool. Cryptosporidium oocysts were detected as the sole pathogen in 21 diarrheic cases. Cryptosporidium was found exclusively in the specimens collected during the rainy season: 21 of 21 oocyst-positive with diarrhea and 27 of 28 oocyst-positive without diarrhea. Again, the difference in incidence between the sexes was not remarkable. The oocyst-positive rate of patients with diarrhea was significantly higher in the

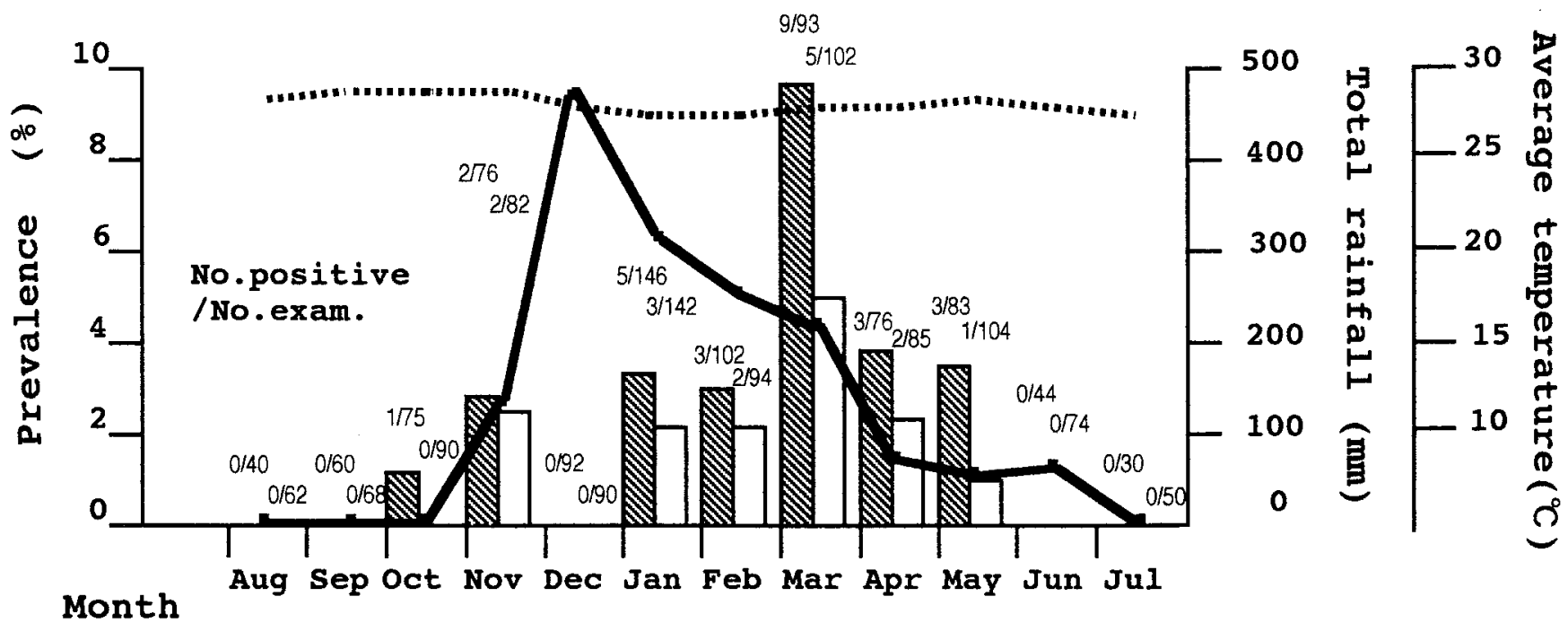

FIGURE 1. Seasonality of prevalence of Cryptosporidium parvum infection in a hospital-based study. Hatched bars $=$ patients with diarrhea; open bars $=$ patients without diarrhea; solid line $=$ total rainfall $(\mathrm{mm})$; dashed line $=$ average temperature $\left({ }^{\circ} \mathrm{C}\right)$; exam. $=$ examined. 
TABLE 2

Results of stool examination for Cryptosporidium parvum oocysts in a community-based study

\begin{tabular}{|c|c|c|c|c|c|}
\hline \multicolumn{6}{|c|}{ Rainy season (December 1992-March 1993) } \\
\hline & & \multicolumn{2}{|c|}{ Diarrheic stool } & \multicolumn{2}{|c|}{ Nondiarrheic stool } \\
\hline & & $\begin{array}{l}\text { No. } \\
\text { exam- } \\
\text { ined }\end{array}$ & $\begin{array}{l}\text { No. } \\
\text { positive } \\
\text { for } \\
\text { oocysts } \\
(\%)\end{array}$ & $\begin{array}{l}\text { No. } \\
\text { exam- } \\
\text { ined }\end{array}$ & $\begin{array}{c}\text { No. } \\
\text { positive } \\
\text { for } \\
\text { oocysts } \\
(\%)\end{array}$ \\
\hline Age (years) & $\begin{array}{l}0-1 \\
2-4 \\
5-9 \\
\geq 10\end{array}$ & $\begin{array}{l}53 \\
61 \\
65 \\
26\end{array}$ & $\begin{array}{r}10(19) \\
4(6.6) \\
6(9.2) \\
1(3.8)\end{array}$ & $\begin{array}{l}506 \\
314 \\
496 \\
887\end{array}$ & $\begin{array}{r}6(1.2) \\
8(2.5) \\
11(2.2) \\
2(0.2)\end{array}$ \\
\hline Sex & $\begin{array}{l}\text { Male } \\
\text { Female }\end{array}$ & $\begin{array}{r}85 \\
120\end{array}$ & $\begin{array}{r}9(11) \\
12(10)\end{array}$ & $\begin{array}{l}1,087 \\
1,116\end{array}$ & $\begin{array}{l}15(1.4) \\
12(1.1)\end{array}$ \\
\hline Total & & 205 & $21(10)$ & 2,203 & $27(1.2)$ \\
\hline \multicolumn{6}{|c|}{ Dry season (June 1993-July 1993) } \\
\hline & & \multicolumn{2}{|c|}{ Diarrheic stool } & \multicolumn{2}{|c|}{ Nondiarrheic stool } \\
\hline & & $\begin{array}{l}\text { No. } \\
\text { exam- } \\
\text { ined }\end{array}$ & $\begin{array}{l}\text { No. } \\
\text { positive } \\
\text { for } \\
\text { oocysts } \\
(\%)\end{array}$ & $\begin{array}{c}\text { No. } \\
\text { exam- } \\
\text { ined }\end{array}$ & $\begin{array}{l}\text { No. } \\
\text { positive } \\
\text { for } \\
\text { oocysts } \\
(\%)\end{array}$ \\
\hline Age (years) & $\begin{array}{l}0-1 \\
2-4 \\
5-9 \\
\geq 10\end{array}$ & $\begin{array}{r}9 \\
20 \\
13 \\
10\end{array}$ & $\begin{array}{l}0(0) \\
0(0) \\
0(0) \\
0(0)\end{array}$ & $\begin{array}{l}468 \\
230 \\
465 \\
745\end{array}$ & $\begin{array}{l}0(0) \\
0(0) \\
1(0.2) \\
0(0)\end{array}$ \\
\hline Sex & $\begin{array}{l}\text { Male } \\
\text { Female }\end{array}$ & $\begin{array}{l}20 \\
32\end{array}$ & $\begin{array}{l}0(0) \\
0(0)\end{array}$ & $\begin{array}{l}972 \\
936\end{array}$ & $\begin{array}{l}0(0) \\
1(0.1)\end{array}$ \\
\hline Total & & 52 & $0(0)$ & 1,908 & $1(0.05)$ \\
\hline
\end{tabular}

group younger than two years old than in the older age groups $(P<0.05)$.

Cryptosporidium parvum oocysts were found in feces of 13 cats $(2.4 \%)$ in our study area, but were not found in dogs. Although a cat positive for Cryptosporidium was known to actually reside in the household with an infected individual, a specific link between cats shedding oocysts and individuals in that home who were shedding oocysts could not be examined. There are three reasons for this difficulty. 1) Since oocysts are excreted during a short period, ${ }^{17}$ it is necessary to examine the stool of both human and cats at the same time. However, there was a time lag between the examination of stool of humans and cats in our study. 2) It was impossible to identify by questionnaire the cat that made contact with these individuals. 3) The cats are free to move around the community.

Statistical analysis was performed to test possible risk factors related to shedding of Cryptosporidium oocysts. Logistic regression model was used to perform multiple comparison between oocysts with the participant's name, sex, consistency and nature of stool, socioeconomic indicators, dwelling characteristics, and hygienic indicators (Table 3). These comparative analyses showed that the following factors were independently associated with an increased risk of Cryptosporidium infection: 1) rainy season, 2) contact with cats, 3) diarrhea, 4) flood, and 5) number of people in a household. This analysis also showed that age was likely to decrease the risk of infection. Other factors such as sex, untreated drinking water, public bath bathing, number of rooms in a household, and residence had no apparent influence on Cryptosporidium transmission in our study area.

\section{DISCUSSION}

The importance of Cryptosporidium as a widespread cause of diarrhea is now recognized. ${ }^{18,19}$ Reported prevalences of Cryptosporidium infection in Asia range from 3.6\% in China, ${ }^{20} 4.3 \%$ in Bangladesh, ${ }^{21} 13.1 \%$ in India, ${ }^{22}$ and $3.2 \%$ in Thailand. ${ }^{23}$ The infection rate observed in the present study is lower than those reported elsewhere. However, Cryptosporidium oocysts were identified as the sole pathogen in 23 of 26 diarrheic samples obtained in a hospital and in all of

TABLE 3

Odds ratios and $95 \%$ confidence intervals for the association of Cryptosporidium parvum infection and selected factors

\begin{tabular}{|c|c|c|c|c|c|c|}
\hline \multirow[b]{2}{*}{ Factors } & \multicolumn{2}{|c|}{ Cases } & \multicolumn{2}{|c|}{ Controls } & \multirow[b]{2}{*}{$\begin{array}{l}\text { Odds } \\
\text { ratio }\end{array}$} & \multirow[b]{2}{*}{$\begin{array}{l}95 \% \text { confidence } \\
\text { interval }\end{array}$} \\
\hline & $\begin{array}{c}\text { No. } \\
\text { exposed }\end{array}$ & $\begin{array}{l}\text { No. of } \\
\text { respondents }\end{array}$ & $\begin{array}{c}\text { No. } \\
\text { exposed }\end{array}$ & $\begin{array}{l}\text { No. of } \\
\text { respondents }\end{array}$ & & \\
\hline Age (years)* & \multicolumn{2}{|c|}{$5.397 \pm 9.331$} & \multicolumn{2}{|c|}{$11.676 \pm 13.104$} & 0.946 & $0.897-0.998$ \\
\hline Male (sex) & 27 & 49 & 2,178 & 4,319 & 1.075 & $0.564-2.050$ \\
\hline Rainy season & 48 & 49 & 2,360 & 4,319 & 10.655 & $1.382-82.177$ \\
\hline Diarrhea & 21 & 49 & 236 & 4,319 & 3.985 & $1.986-7.999$ \\
\hline Contacting with cats & 25 & 49 & 201 & 2,004 & 7.053 & $3.615-13.760$ \\
\hline Drinking untreated water & 3 & 49 & 47 & 2,011 & 1.793 & $0.343-9.369$ \\
\hline Bathing in public bath & 14 & 49 & 243 & 2,021 & 1.727 & $0.774-3.853$ \\
\hline Flood & 36 & 49 & 698 & 2,007 & 3.083 & $1.935-4.912$ \\
\hline No. of persons/house* & \multicolumn{2}{|c|}{$5.653 \pm 1.678$} & \multicolumn{2}{|c|}{$5.096 \pm 1.479$} & 1.463 & $1.196-1.790$ \\
\hline No. of rooms/house* & \multicolumn{2}{|c|}{$2.327 \pm 0.774$} & \multicolumn{2}{|c|}{$2.765 \pm 1.119$} & 0.714 & $0.494-1.031$ \\
\hline \multicolumn{7}{|l|}{ Area } \\
\hline N1 & 2 & 49 & 383 & 4,319 & 0.448 & $0.074-2.691$ \\
\hline $\mathrm{N} 2$ & 2 & 49 & 441 & 4,319 & 0.813 & $0.140-4.715$ \\
\hline $\mathrm{E} 1$ & 22 & 49 & 1,357 & 4,319 & 0.796 & $0.241-2.630$ \\
\hline E2 & 3 & 49 & 409 & 4,319 & 1.032 & $0.214-4.976$ \\
\hline $\mathrm{C} 1$ & 4 & 49 & 589 & 4,319 & 1.434 & $0.331-6.209$ \\
\hline $\mathrm{C} 2$ & 9 & 49 & 285 & 4,319 & 1.665 & $0.426-6.505$ \\
\hline $\mathrm{S}$ & 2 & 49 & 349 & 4,319 & 0.891 & $0.140-5.670$ \\
\hline $\mathrm{W} \dagger$ & 5 & 49 & 506 & 4,319 & - & - \\
\hline
\end{tabular}

Area W was used as a referent. 
21 diarrheic samples obtained in the community. The higher prevalence in children and seasonality of infection observed in our study are similar to those in studies reported elsewhere. ${ }^{1,2,4-7,10,19}$ Thus, the present study demonstrates that Cryptosporidium is an important pathogen associated with diarrhea in children and in the rainy season in Surabaya, Indonesia. Since it was necessary to examine a large number of specimens, we first examined smears concentrated by a floatation technique by phase-contrast microscopy for more rapid viewing. The examination of oocysts by phase- contrast microscopy is reported to be as sensitive as that by a conventional acid-fast staining technique that stain oocysts in preparations made by a sedimentation technique. ${ }^{18}$

An immunodeficient state, age, malnutrition, nonbreastfed/being weaned at an early age, water source, contact with animals, and crowded living conditions have been reported as the possible risk factors of transmission of Cryptosporidium. 5,6,16,17,24 The present study has identified as risk factors domestic cats, number of people in a household, rainy seasons, and flooding. The occurrence of disease could be partially due to the presence of cats as the potential reservoir host since there were a large number of cats in our study area. The present study showed that $2.4 \%$ of the cats were shedding Cryptosporidium oocysts. Although the infection rate of cats in this study was lower than those reported in other studies, ${ }^{25,26}$ cats may play an important role in the transmission of disease in terms of cat-human contact or environmental contamination by shedding oocysts. In Brazil, animals serve as a reservoir of Cryptosporidium, with the potential for contamination of immediate household water sources. ${ }^{16}$ The crowded conditions in a household can also facilitate human-to-human contact and result in the concentration of the infection in the families with many people. A high secondary infection rate $(39 \%)$ was reported in the households in which children with Cryptosporidium infection were identified. ${ }^{11}$ Another factor would be heavy rains and flooding that could lead to the spread of environmental contamination by oocysts and favor water-borne transmission of Cryptosporidium. Although drinking boiled water is a common practice among individuals in our study area, unboiled water would probably be used for food preparation, washing, hands, and taking baths.

In conclusion, our finding suggests that Cryptosporidium is an important pathogen in Surabaya and poor living conditions are a contributing factor for the transmission of this parasite. We believe that health education and better household hygiene are essential for the prevention of Cryptosporidium infection in this area.

Acknowledgments: We are indebted to Dr. Shoji Uga (University of Kobe, Hyogo, Japan), Dr. Satoshi Nakamura (University of Ryukyu, Okinawa, Japan), and Dr. Yoshiki Aoki (University of Nagasaki) for providing information and advice.

Financial support: This study was supported by Japan International Cooperation Agency.

Authors' addresses: Tatsuya Katsumata, Department of Parasitology, Institute of Tropical Medicine, Nagasaki University, 1-12-4 Sakamoto, Nagasaki 852, Japan. Daniel Hosea, Eddy Bagus Wasito, Pitono Soeparto, Ign Gde Ranuh, Tropical Disease Research Center, Airlangga University, JL, Dharmahusada 47, Surabaya, Indonesia. Shigeru Kohno and Kohei Hara, Second Department of Internal
Medicine, Nagasaki University School of Medicine, 1-7-1 Sakamoto, Nagasaki 852, Japan.

Reprint requests: Tatsuya Katsumata, Department of Parasitology, Institute of Tropical Medicine, Nagasaki University, 1-12-4 Sakamoto, Nagasaki 852, Japan.

\section{REFERENCES}

1. Mata L, Bolanos H, Pizarro D, Vives M, 1984. Cryptosporidiosis in children from some highland Costa Rican rural and urban areas. Am J Trop Med Hyg 33: 24-29.

2. Pal S, Bhattacharya SK, Das P, Chaudhuri P, Dutta P, De SP, Sen D, Saha MR, Nair GB, Pal SC, 1989. Occurrence and significance of Cryptosporidium infection in Calcutta. Trans $R$ Soc Trop Med Hyg 83: 520-521.

3. Miller K, Pinales CD, Lopez AC, Lechuga LM, Taren D, Enriquez FJ, 1994. Cryptosporidium parvum in children with diarrhea in Mexico. Am J Trop Med Hyg 51: 322-325.

4. Bonilla LC, Young MM, Cano G, Guanipa N, Estevez J, Bonilla E, 1993. Cryptosporidium infections in a suburban community in Maracaibo, Venezuela. Am J Trop Med Hyg 49: 6367.

5. Fayer R, Ungar BLP, 1986. Cryptosporidium spp. and cryptosporidiosis. Microbiol Rev 50: 458-483.

6. Tzipori S, 1988. Cryptosporidiosis in perspective. Adv Parasitol 27: $63-129$.

7. Nimri LF, Batchoun R, 1994. Prevalence of Cryptosporidium species in elementary school children. J Clin Microbiol 32. $1040-1042$.

8. Cruz JR, Cano F, Caceres P, Chew F, Pareja G, 1988. Infection and diarrhea caused by Cryptosporidium sp. among Guatemalan infants. J Clin Microbiol 26: 88-91.

9. Højlyng N, Mølbak K, Jepsen S, 1986. Cryptosporidium spp., a frequent cause of diarrhea in Liberian children. J Clin Microbiol 23: 1109-1113.

10. Adegbola RA, Demba E, De Veer G, Todd J, 1994. Cryptosporidium infection in Gambian children less than 5 years of age. J Trop Med Hyg 97: 103-107.

11. Newman RD, Zu SX, Wuhib T, Lima AAM, Guerrant RL, Sears CL, 1994. Household epidemiology of Cryptosporidium parvum infection in an urban community in northeast Brazil. Ann Intern Med 120: 500-505.

12. Hayes EB, Matte TD, O'Brien TR, McKinley TW, Logsdon GS, Rose JB, Ungar BLP, Word DM, Pinsky PF, Cummings ML, Wilson MA, Long EG, Hurwitz ES, Juranek DD, 1989. Large community outbreak of cryptosporidiosis due to contamination of a filtered public water supply. $N$ Engl J Med 320: 1372-1376.

13. Current WL, Reese NC, Ernst JV, Bailey WS, Heyman MB, Weinstein WM, 1983. Human cryptosporidiosis in immunocompetent and immunodeficient persons: studies of an outbreak and experimental transmission. $N$ Engl J Med 308: $1252-1257$.

14. Alpert G, Bell LM, Kirkpatrick CE, Budnick LD, Campos JM, Friedman HM, Plotkin SA, 1984. Cryptosporidiosis in a daycare center. $N$ Engl J Med 311: 860-861.

15. Blagburn BL, Current WL, 1983. Accidental infection of a researcher with human Cryptosporidium. J Infect Dis 148: 772773.

16. Newman RD, Wuhib T, Lima AAM, Guerrant RL, Sears CL, 1993. Environmental sources of Cryptosporidium in an urban slum in northeastern Brazil. Am J Trop Med Hyg 49: 270275.

17. Current WL, Garcia LS, 1991. Cryptosporidiosis. Clin Microbiol Rev 4: 325-358.

18. O'Donoghue PJ, 1995. Cryptosporidium and cryptosporidiosis in man and animals. Int J Parasitol 25: 139-195.

19. Martins CAP, Guerrant RL, 1995. Cryptosporidium and cryptosporidiosis. Parasitol Today 11: 434-436.

20. Chen YG, Yao FB, Li HS, Shi WS, Dai MX, Lu M, 1992. Cryptosporidium infection and diarrhea in rural and urban ar- 
eas of Jiangsu, People's Republic of China. J Clin Microbiol 30: $492-494$.

21. Shahid NS, Rahman ASMH, Anderson BC, Mata LJ, Sanyal SC, 1985. Cryptosporidiosis in Bangladesh. Br Med J 290: 114-115.

22. Mathan MM, Venkatesan S, George R, Mathew M, Mathan VI, 1985. Cryptosporidium and diarrhoea in southern Indian children. Lancet ii: 1172-1175.

23. Taylor DN, Echeverria P, 1986. When does Cryptosporidium cause diarrhoea? Lancet $i$ : 320.
24. Zu SX, Guerrant RL, 1993. Cryptosporidiosis. J Trop Pediatr 39: $132-136$.

25. Uga S, Matsumura T, Ishibashi K, Yoda Y, Yatomi K, Kataoka $\mathrm{N}, 1989$. Cryptosporidiosis in dogs and cats in Hyogo prefecture, Japan. Jpn J Parasitol 38: 139-143.

26. Arai H, Fukuda Y, Hara T, Funakoshi Y, Kaneko S, Yoshida T, Asahi H, Kumada M, Kato K, Koyama T, 1990. Prevalence of Cryptosporidium infection among domestic cats in the Tokyo metropolitan district, Japan. Jpn J Med Sci Biol 43: 714. 